\title{
Investigation of the lower extremity fractures in children who applied to the emergency department of university hospital
}

\section{Üniversite hastanesi acil servisine başvuran çocuklarda alt ekstremite kırıklarının araştırılması}

\author{
Hilal Irmak Sapmaz, 1 (1) Mehmet Esen² \\ 'Department of Anatomy, Tokat Gaziosmanpasa University Faculty of Medicine, Tokat, Turkey \\ ${ }^{2}$ Department of Emergency Medicine, Tokat Gaziosmanpasa University Faculty of Medicine, Tokat, Turkey
}

\begin{abstract}
Introduction: Although bones are more flexible and have higher shock absorption ability in childhood than in adulthood, bone fractures are often seen in children who present to the emergency clinics after a trauma. This study was conducted to identify the pattern and the rate of traumatic lower extremity fractures in children.

Methods: Files and X-rays of 485 patients aged under 18 years who presented to the Emergency Department of the Tokat Gaziosmanpaşa University Healthcare Research and Application Hospital after a trauma were retrospectively reviewed. Data of 146 children who presented with a trauma to the lower extremity were examined. Fractures were assessed based on age groups, gender, etiology, and the affected bone.

Results: Of the 146 children who presented with a trauma to the lower extremity, 112 were male (77\%) and 34 were female (23\%). Traumas had been mostly experienced in the summer, followed by spring, autumn, and winter. The femur was the most commonly affected bone among the fractures caused by a trauma $(n=32$, $33.33 \%)$. Single-bone fractures most commonly involved the femur, followed by the tibia, the phalanx, and the metatarsal bones, whereas double-bone fractures most commonly involved the tibia and the fibula. Falling down was the major cause of trauma

Discussion and Conclusion: We believe that the results of our study will help to better understand the occurrence of traumatic lower extremity fractures in children and offer guidance for taking the protective measures that will help to protect them, hence, to reduce fractures.
\end{abstract}

Keywords: Children; fracture; lower extremity; trauma.
Özet

Amaç: Çocuklarda kemikler erişkinlere göre daha esnek olmasına ve daha yüksek absorbsiyon özelliğine sahip olmasına rağmen acil servislere travma ile başvuran çocuklarda kırıklara sıklıkla rastlanmaktadır. Bu çalışma çocuklardaki travmatik alt ekstremite kırıklarının dağıımının ve sıkığının değerlendirilmesi için yapıldı.

Gereç ve Yöntem: Tokat Gaziosmanpaşa Üniversitesi Sağlık Araştırma ve Uygulama Hastanesi Acil Servisine travma nedeni ile başvuran 18 yaş altı hastalardan 485 çocuğun dosyaları ve düz grafileri retrospektif olarak değerlendirildi. Alt ekstremite travması ile geldiği tespit edilen 146 çocuğun verileri incelendi. Yaş gruplarına, cinsiyetlerine, etyolojiye ve etkilenen kemiğe göre kırıklar değerlendirildi.

Bulgular: Alt ekstremite travması ile gelen 146 çocuktan 112'si (\%77) erkek, 34'ü (\%23) ise kızdı. Travmaların en çok yaz mevsiminde yaşandığı bunu azalan sırayla ilkbahar, sonbahar ve kışın takip ettiği belirlendi. Travmaya bağlı oluşan kırıklarda en çok etkilenen kemik femur ( $n=32, \% 33.33$ ) idi. Tek kemik kırıkları arasında da en sık femur kırığı bulunup bunu sırayla tibia, falanks, metatars kırıkları izliyordu. Çift kemik kırıkları arasında ise en çok tibia ve fibula kırıkları görüldü. Etyolojide ilk sırayı düşme alıyordu.

Sonuç: Çalışma sonuçlarımızın çocuklardaki travmatik alt ekstremite kırıklarının daha iyi anlaşılmasına ve böylelikle koruyucu önlemlerin alınarak kırıkların azaltılıp çocukların korunmasına katkı sağlayacağı kanaatindeyiz.

Anahtar Sözcükler: Çocuklar; kırık; alt ekstremite; travma. 
$B^{o}$ one fractures in children and adolescents are commonly presented to the emergency rooms (ER), can often lead to orthopedic problems and should be treated immediately. [1] Of the children who present to the ER after a trauma, 10$25 \%$ are reported to have a bone fracture. ${ }^{[1-3]}$ Force exerted on the bones, such as pushing, pulling or pressure, can alter the structure, the integrity and the shape of the bone. While inorganic salts stored in the bones are responsible for the stabilization of its structure, organic components are responsible for its flexibility. ${ }^{[4,5]}$ The high flexibility and the high absorption ability of the bones in children reduce both fracture formation and the incidence of segmental fractures. ${ }^{[6]}$ Exercise, nutrition and exposure to sunlight have a direct effect on the flexibility and resilience of the bones. ${ }^{[7,8]}$

Fractures occur when a force greater than its resilience is exerted on the bone. The resulting fracture can vary from a small fissure to segmental fractures. The force exerted on the bone can even cause damage to the surrounding muscles, skin, tendons, vascular structures and nerve fibers. ${ }^{[9-11]}$ While bone fractures are mostly caused by falls, traffic accidents and assaults in childhood, more often the cause is traffic and occupational accidents in the middle ages and traffic accidents in the advanced ages. While fractures of the upper extremities are more commonly seen in children, fractures of the lower extremities are more frequent among elderly adults. ${ }^{[12-14]}$

Whereas many of the traumas experienced in childhood can be prevented with simple measures. However these traumas are still an important source of morbidity and mortality. Falling down, in particular, is seen to be the most common reason for visiting the ER and one that causes fractures among all age groups.

In this study, we retrospectively explored the epidemiological and clinical characteristics of the child trauma patients who presented to the ER of our hospital with fractures in the lower extremities.

\section{Materials and Method}

Ethics committee approval (nr: 18-KAEK-227) has been obtained for this study. Files and X-rays of patients aged under 18 years who presented to the ER of the Tokat Gaziosmanpaşa University Research and Application Hospital from January 2012 to December 2017 after a trauma were retrospectively evaluated. Evaluations were conducted using the hospital information system (ENLIL and PACS). Based on the data obtained from the files of the child patients with a trauma involving the lower extremity, age groups were defined as 0-4, 5-8, 9-12 and 13-17. Those with a history of neuromuscular disease and with a pathologic fracture were excluded.

\section{Statistical analysis}

The data were analyzed using the SPSS 20 software package. The groups were compared using the Chi-square test. A pvalue less than 0.05 was accepted as significant.

\section{Results}

Files of 485 children who presented to the ER of the Tokat Gaziosmanpaşa University Research and Application Hospital following a trauma were reviewed. Presence of a pathology involving the lower extremity was identified in 146 of the cases. Of these child patients 112 were male (77\%) and 34 were female (23\%). Traumas had mostly occurred in the summer, followed by spring, autumn and winter months (Fig. 1). Children were identified to have experienced a trauma most commonly in the month of August ( $n=19,13 \%)$ and least commonly in the month of January ( $n=5,3.4 \%$ ) (Fig. 2). Across all age groups, a higher number of traumas to the lower extremity was reported in boys than in girls (Fig. 3). This difference was statistically significant $(p<0.05)$. A fracture was reported in 96 of the 146 children who had experienced a trauma to the lower extremity. The femur was the most commonly affected bone among the fractures caused by a trauma ( $n=32,33.33 \%$ ) (Fig. 4). Isolated femoral fractures were the most common type among sin-

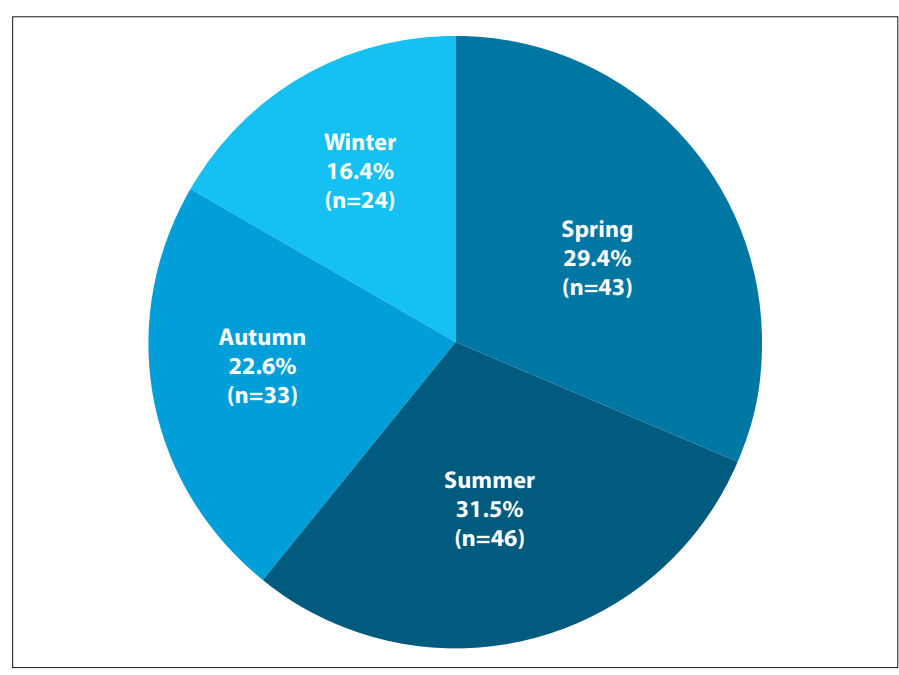

Figure 1. Distribution of lower extremity trauma cases by seasons.

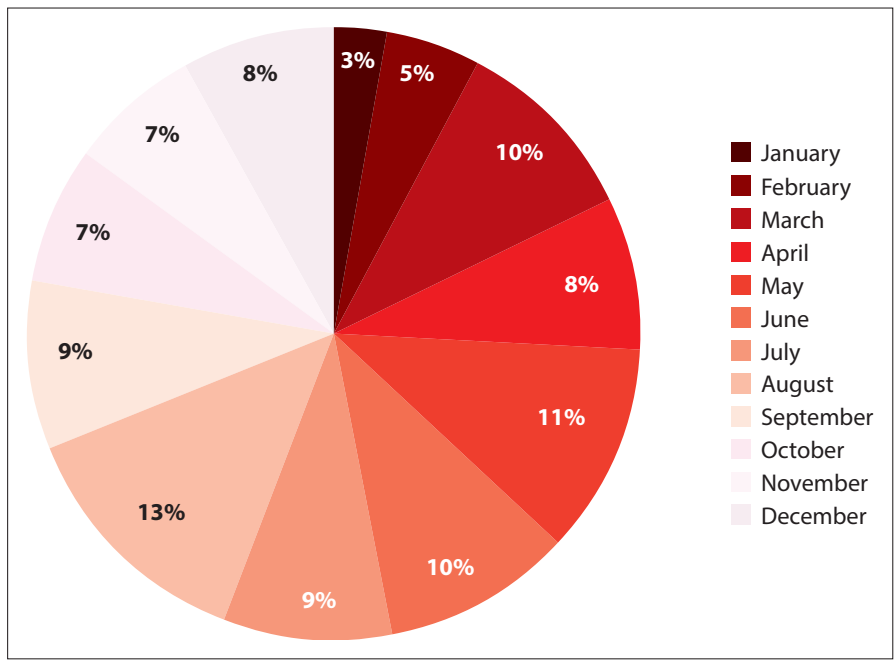

Figure 2. Distribution of lower extremity trauma percentages by months. 


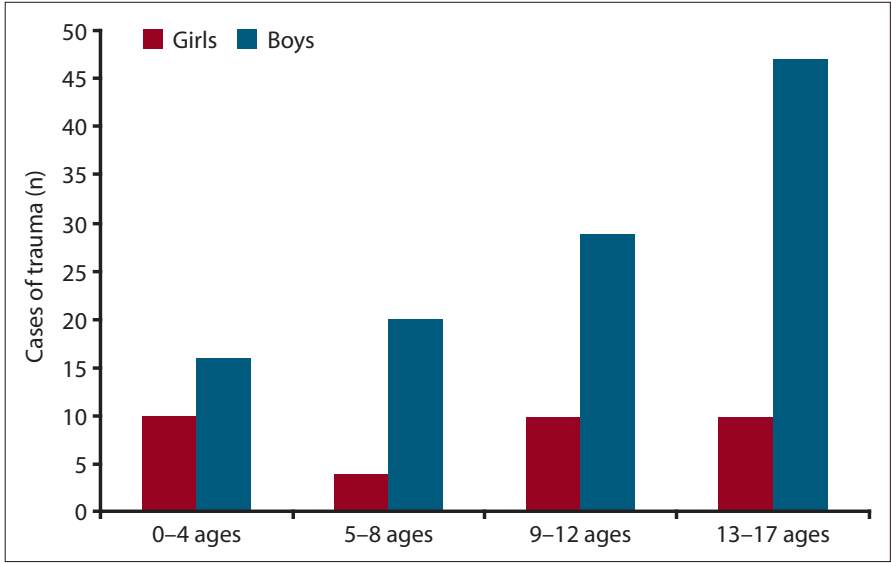

Figure 3. Distribution of lower extremity trauma cases by genders.

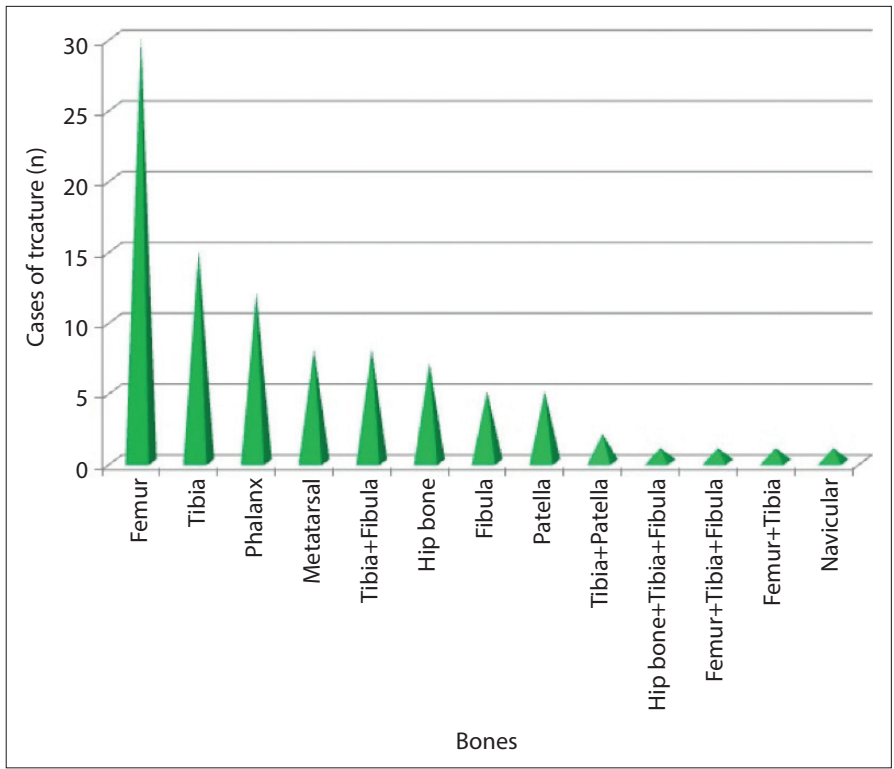

Figure 4. Distribution of lower extremity trauma cases by genders.

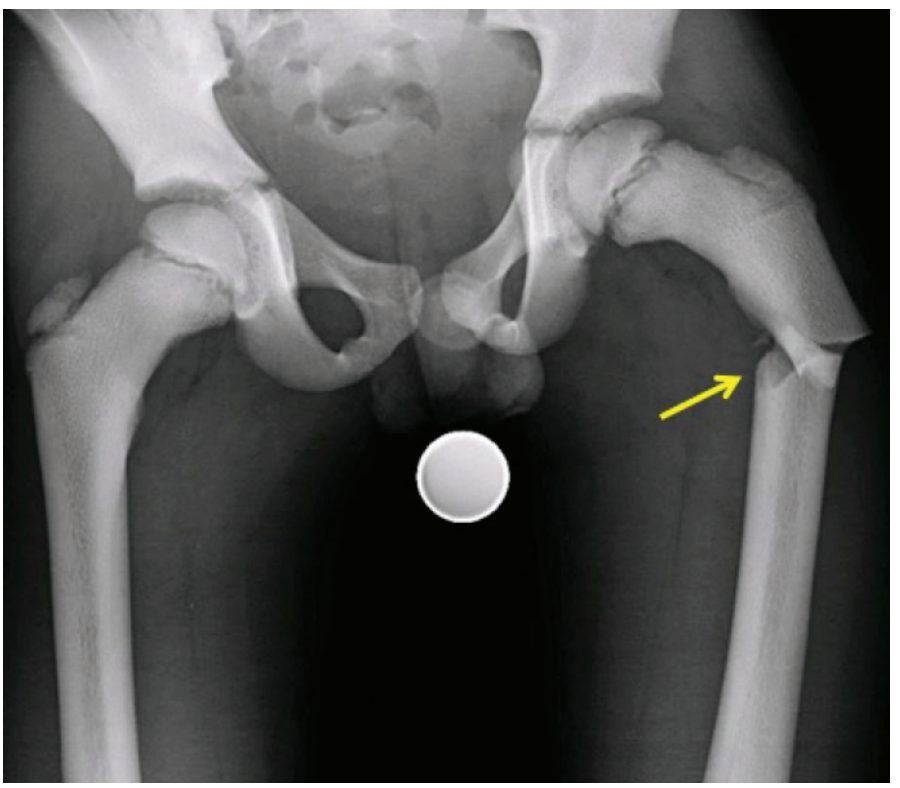

Figure 5. Femoral fracture.

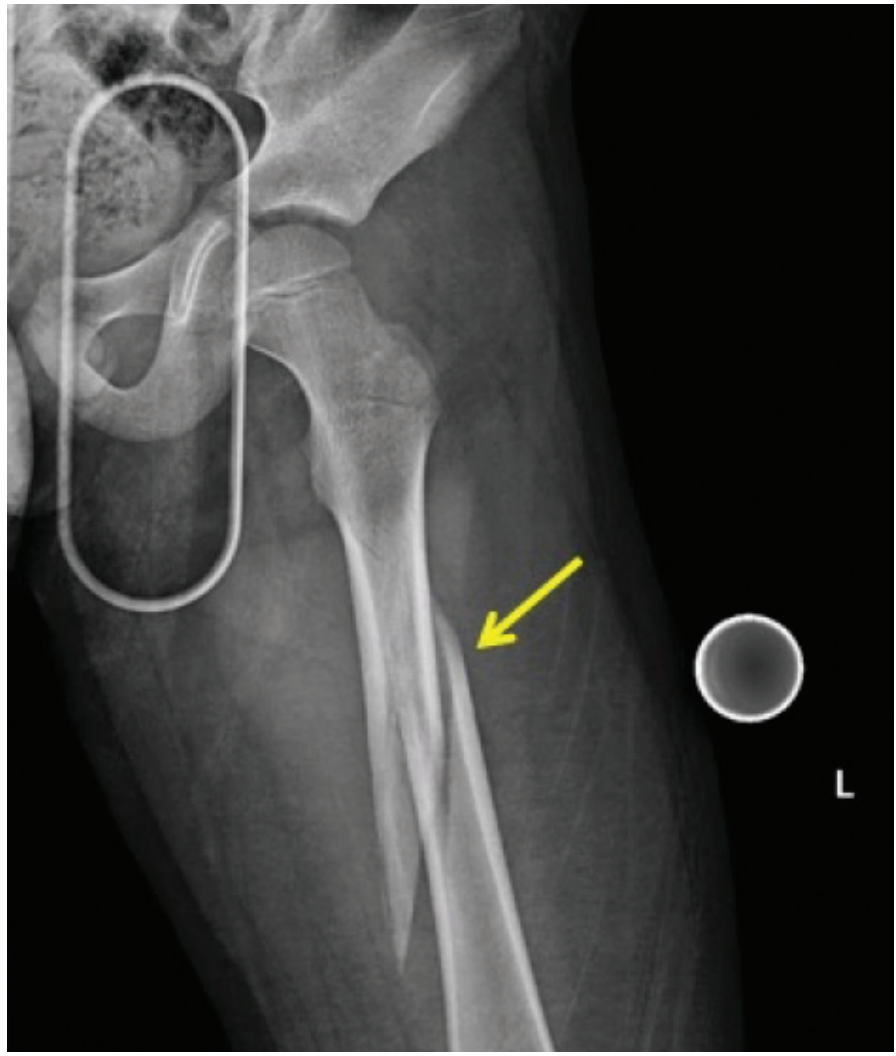

Figure 6. Femoral shaft fracture.

gle-bone fractures ( $n=30)$ (Fig. 5, 6), followed, in a descending order, by the isolated fractures of the tibia, the phalanx, and the metatarsal bones, and the fractures of the hip bone, the fibula, and the patella (Fig. 7-9). Double-bone fractures most commonly involved the tibia and the fibula (Fig. 10). Review of the fracture sites on the long bones revealed the femur shaft to be the most affected site (Fig. 6). Etiology of lower extremity pathologies showed falling as the top cause (31.62\%). Same level falls were reported as the most common reason of injury. This was followed by out-of-vehicle traffic accidents, in-vehicle traffic accidents and spraining. Although less common, dropping a heavy item on the extremity, injuries caused by a sharp object like a power saw or an ax were among the reported reasons of injury. Falling down $(n=17)$ was the most common and traffic accident $(n=13)$ was the second most common cause in the etiology of the femoral fractures.

Apart from fractures, the most common lesions caused by a trauma to the lower extremity were injury by a foreign object, amputation and soft tissue injuries.

\section{Discussion}

Today, children can be exposed to a range of traumas in their daily life, and fractures caused by these traumas constitute a major part of the emergency cases experienced in childhood. The frequency of fractures seen in childhood considerably varies according to age, season and sociocultural characteristics. ${ }^{[15]}$ Factors such as carelessness in organizing play areas, 


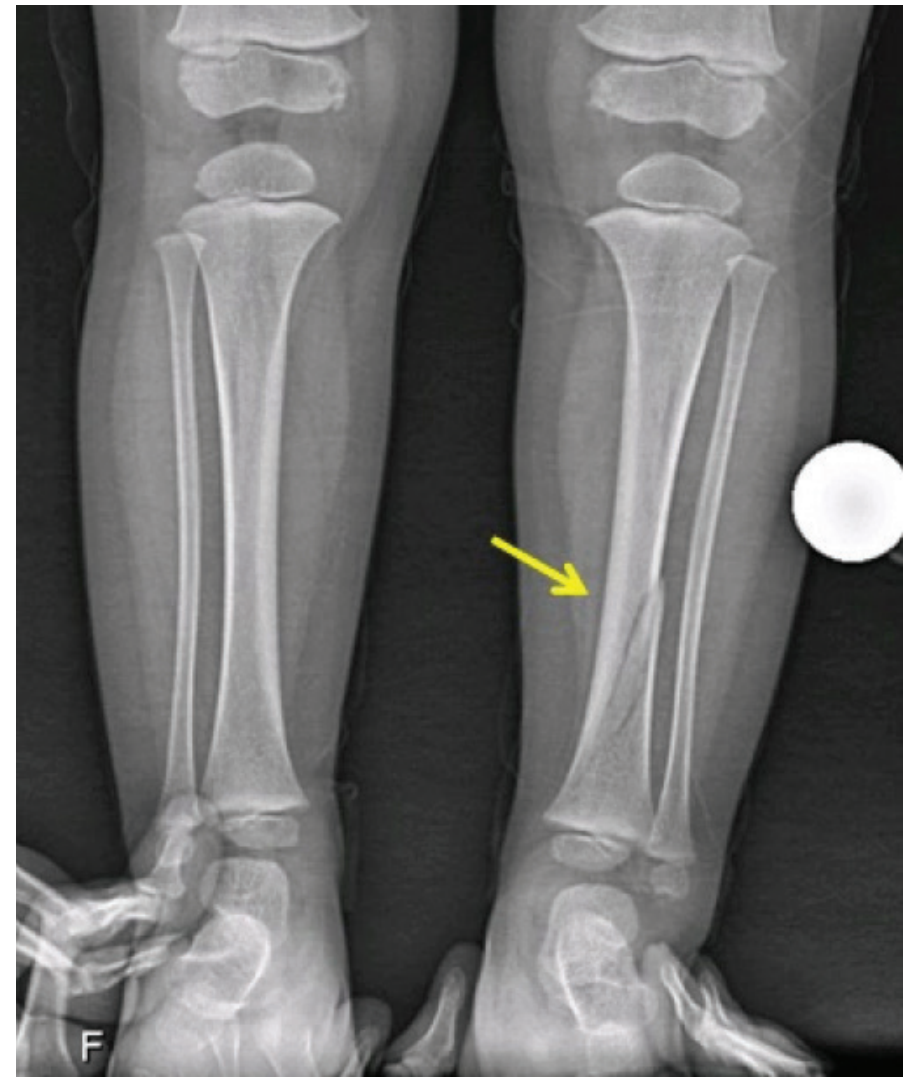

Figure 7. Isolated fracture of tibia.

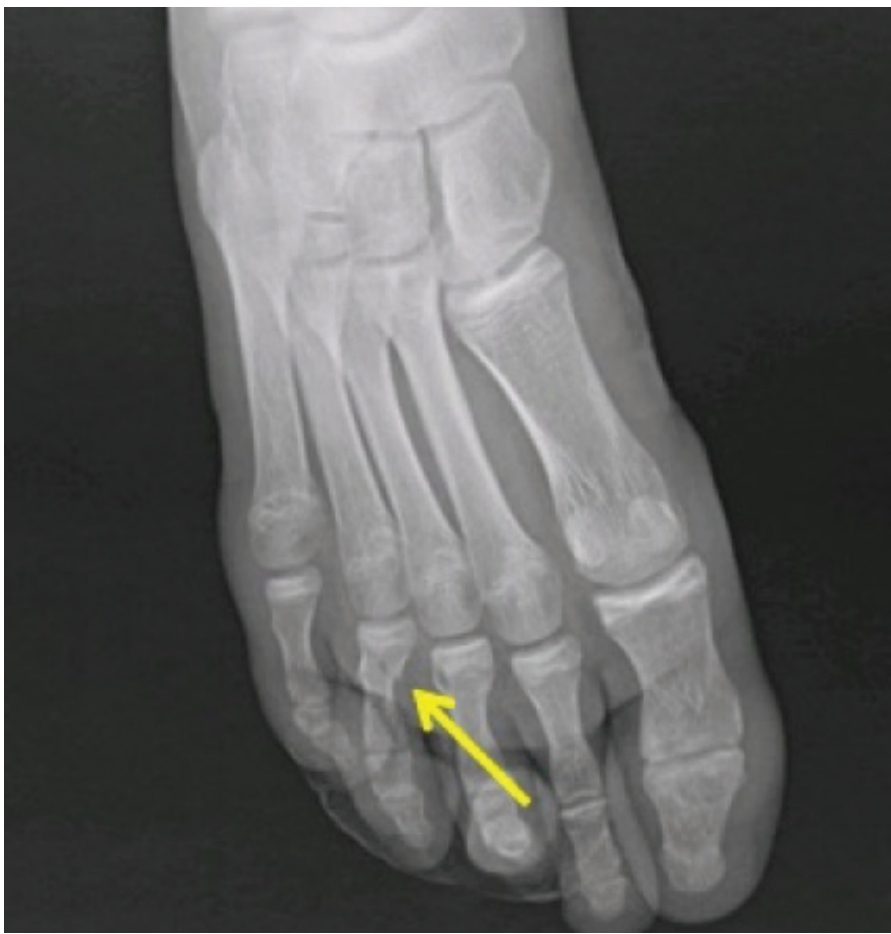

Figure 8. Fracture of the phalanx.

the increasing number of traffic accidents due to the substantial rise in the number of vehicles on the roads, the increased rate of working parents all contribute to the increased num-

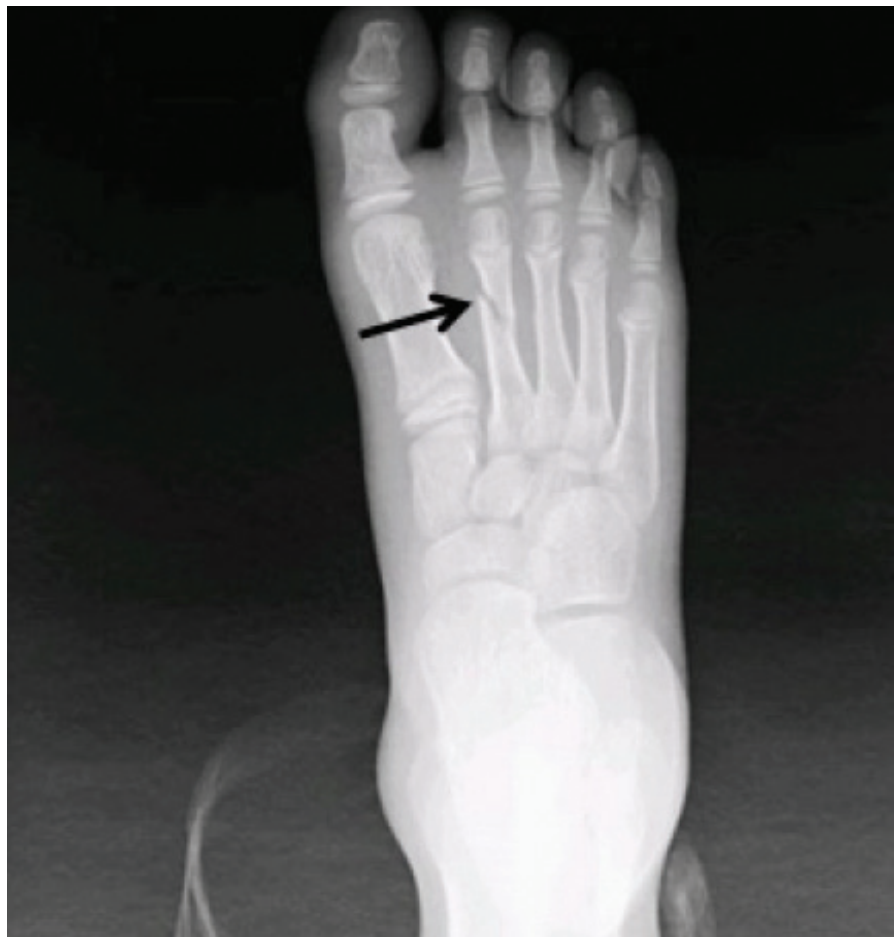

Figure 9. Fracture of the metatars.

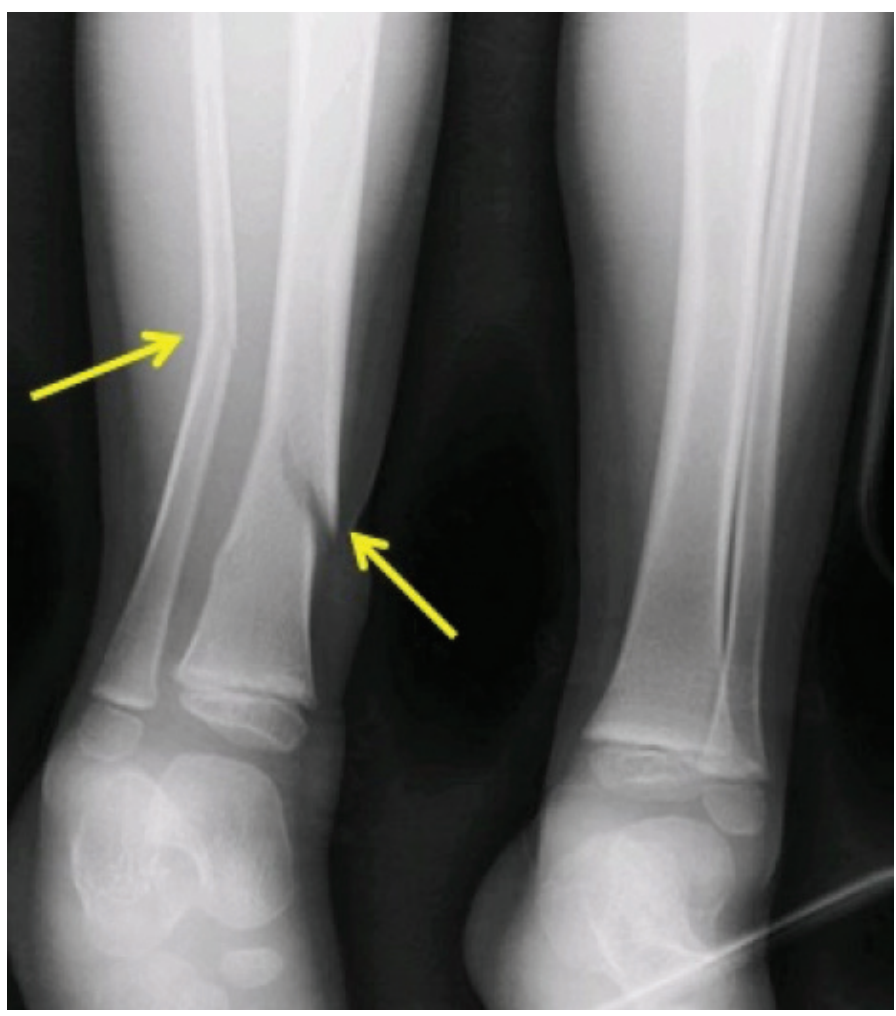

Figure 10. Fracture of the tibia and fibula.

ber of fractures in children. ${ }^{[16]}$ In addition to the dynamism of children and absence of a fully-developed self-protection mechanism, parents' failure to lookout for and monitor their children are among the causes that lead to the rise in childhood traumas. ${ }^{[12]}$ 
In many studies, the majority of the trauma cases that present to the ER are reported to be boys. ${ }^{[8,14,17]}$ McKenzie et al. report that of the children who presented to the ER in the years from 1990 to 2008 following a trauma $89 \%$ were boys and $11 \%$ were girls. ${ }^{[17]}$ Likewise, in our study, we found a higher rate of lower extremity fractures in boys. That fractures are more commonly seen in boys than girls can be attributed to the more dynamic, aggressive and adventuresome nature of boys. ${ }^{[18]}$

The incidence of fractures among children varies according to age and the method of injury. While injuries of the upper extremity caused by traumas are more common in the early ages, the rate of injuries of the lower extremity is $18.1 \%$ in the $5-10$ age group, $29.6 \%$ in the $11-14$ age group, and $42.1 \%$ in the $15-19$ age group. ${ }^{[17]}$ Fractures caused by falling are mostly reported in children under 6 years of age. ${ }^{[19,20]}$ In our study, however, we identified the highest number of lower extremity fractures caused by falling in the 13-17 age group. We identified fractures caused by falling from height to be more common among children over 9 years of age. These results suggest that younger children are less exposed to traumas under the supervision of their parents, caretakers or teachers, and more exposed to traumas with age given their increased mobility and self-confidence whereas they are unable to sufficiently protect themselves. Reports in the literature state sports and traffic accidents, and assaults, as well as falling from height, as the causes of the fractures in older children, and a higher incidence rate of lower extremity fractures than upper extremity fractures. ${ }^{[12,17]}$

Similar to the literature, review of the cases based on the times of the year in our study found lower extremity fractures to be more common in the summer months. This can be explained with the increased outdoor activities of children in the warm season. ${ }^{[21]}$ That $70 \%(n=32)$ of the cases that occurred in the summer months in our study had occurred outdoors and $54 \%$ were traffic accidents supports this fact. The increased number of vacation travels in the summer seasons contribute to an increased traffic, hence accidents on the roads. Moreover, given that our city is an agricultural region, accidents caused by tractors are also commonly seen in summer. Unlike our findings, some studies report increased number of fracture incidences in children during the autumn months. ${ }^{[22,23]}$ Park et al. report to have found femoral and tibial shaft fractures to be more common in the winter months. The authors also report to have found minor differences among the seasons and suggest that this could be due to the slippery roads, reduced vision and decrease in vitamin D metabolism in the winter season. ${ }^{[1]}$

In terms of localization, femoral fractures were the most common, followed by tibial fractures. Studies report that traumatic fractures of the upper extremities are seen at least three times more than those of the lower extremities. ${ }^{[24]}$ Bukley et al. ${ }^{[25]}$ on the other hand, report lower extremity fractures to be higher with a $22 \%$ rate for femoral fractures as the most commonly seen type. In our study, femoral fractures were the most common with a rate of $33.33 \%$.
In conclusion, post-traumatic fractures are among the major causes of morbidity in children. Taking simple measures without restricting their activities is important in preventing morbidity in children ${ }^{[26]}$ We believe that measures such as building sufficient playgrounds to keep children from playing in the streets, creating green spaces around apartment buildings, not letting children alone around hazardous tools and machinery like tractors, axes, power saws, especially in rural areas, and educating parents and caretakers about supervising the children as a potential risk will help reduce the number of such traumas. By reducing the number of traumas, we will first and foremost save lives, reduce incidences of limb losses, and nonetheless reduce healthcare expenses.

Conflict of interest: There are no relevant conflicts of interest to disclose.

\section{References}

1. Park MS, Chung CY, Choi IH et al. Incidence patterns of pediatric and adolescent orthopaedic fractures according to age groups and seasons in South Korea: a population-based study. Clin Orthop Surg 2013;5(3):161-6.

2. Landin LA. Epidemiology of children's fractures. J Pediatr Orthop B 1997;6(2):79-83.

3. Spady DW, Saunders DL, Schopflocher DP et al. Patterns of injury in children: a population-based approach. Pediatrics 2004;113(3 Pt 1):522-9.

4. Arıncı K, Elhan A. Anatomi 1. Cilt. Güneş Tıp Kitabevleri 5. Baskı: Ankara; 2014.

5. Dawson-Hughes B, Harris SS, Krall EA et al. N Engl J Med 1997;4;337(10):670-6. Effect of calcium and vitamin D supplementation on bone density in men and women 65 years of age or older.

6. Currey JD, Butler G. The mechanical properties of bone tissue in children. J Bone Joint Surg Am 1975;57(6):810-4.

7. Chapuy MC, Arlot ME, Duboeuf $F$ et al. Vitamin D3 and calcium to prevent hip fractures in elderly women. $\mathrm{N}$ Engl J Med 1992;327(23):1637-42.

8. Atay T, Tomruk Ö, Çetin GN. Süleyman Demirel Üniversitesi Tıp Fakültesi Acil Servisine Başvuran Çocuk Kırıklarının Epidemiyolojik Değerlendirmesi. Kocatepe Tıp Dergisi 2008;9:17-21.

9. Aydın BK. Pentoksifilin kullanımının kırık iyileşmesi üzerine etkisinin ratlarda incelenmesi, Uzmanlık tezi, İstanbul: Sağlık Bakanlığı Baltalimanı Metin Sabancı Kemik Hastalıkları Eğitim ve Araştırma Hastanesi 1. Ortopedi ve Travmatoloji Kliniği. 2007.

10. Tatar i (Çev. Ed). Anatomi ve Fizyoloji, Nobel Tıp Kitabevleri: Ankara:2017.

11. Polat O. Ekstremite kırıklarına yaklaşım ve tedavi metodolojisi. Acil Tıp Dergisi 2003;3:5-9.

12. Zararsız İ, Kaya E, Savaş N et al. Mustafa Kemal Üniversitesi Tayfur Ata Sökmen Tıp Fakültesi Acil Servise Kırık Nedeniyle Başvuran Hastalarda Kırık Dağılımı ve Sıklığı. Fırat Üniversitesi Sağlık Bilimleri Tıp Dergisi 2009;23;3:155-158.

13. Hadjidakis DJ, Kokkinakis EP, Sfakianakis ME et al. Bone density patterns after normal and premature menopause. Maturitas 2003;44:279-286.

14. Rennie L, Court-Brown CM, Mok JY et al. The epidemiology of fractures in children. Injury 2007;38:913-22. 
15. Wilkins KE. The incidence of fractures in children. In: Rockwood CA, Wilkins KE, Beaty JH. Fractures in children. Vol.3, $4^{\text {th }}$ ed. Philadelphia: Lippincott-Raven, 1996: 3-17.

16. Kalender Ö, Gürcü T, Reisoğlu A et al. Acil servise kırık nedeniyle başvuran çocuk hastalarda kırıkların sıklık ve dağılımı. Acta Orthop Traumatol Turc 2006;40:384-387.

17. McKenzie LB, Fletcher E, Nelson NG et al. Epidemiology of skateboarding-related injuries sustained by children and adolescents 5-19 years of age and treated in US emergency departments: 1990 through 2008. Inj Epidemiol 2016;3(1):10

18. Vane D, Shedd FG, Grosfeld JL et al. An analysis of pediatric trauma deaths in Indiana. J Pediatr Surg 1990;25:955-960.

19. Chang LT, Tsai MC. Craniofacial injuries from slip, trip, and fall accidents of children. J Trauma 2007;63:70-74.

20. Kavaklı A, Savaşer S, Görak G. 0-6 yaş grubundaki çocuklarda karşılaşılan kaza türleri ve sıklığı. Hemşirelik Bülteni 1986;2:7-11.

21. Tiderius CJ, Landin L, Duppe H. Decreasing incidence of frac- tures in children: an epidemiological analysis of 1,673 fractures in Malmo, Sweden, 1993-1994. Acta Orthop Scand 1999;70:622-6.

22. Demirsoy S, Gücüyener K, Günal N, Tunaoğlu S, Bölükbaşı S. Çocukluk çağında 250 kırık olgusunun retrospektif incelenmesi. Artroplasti Artroskopik Cerrahi 1991;2:44-6.

23. Masterson E, Borton D, O'Brien T. Victims of our climate. Injury 1993;24:247-8.

24. Mizuta T, Benson WM, Foster BK et al. Statistical analysis of the incidence of physeal injuries. J Pediatr Orthop 1987;7: 518-23.

25. Buckley SL, Gotschall C, Robertson W Jr et al. The relationships of skeletal injuries with trauma score, injury severity score, length of hospital stay, hospital charges, and mortality in children admitted to a regional pediatric trauma center. J Pediatr Orthop 1994; 14:449-53.

26. Wang $\mathrm{H}, \mathrm{Yu} \mathrm{H}$, Zhou $\mathrm{Y}$ et al. Traumatic fractures as a result of falls in children and adolescents: A retrospective observational study. Medicine (Baltimore) 2017;96(37):e7879. 